\title{
BEKAM SEBAGAI TERAPI ALTERNATIF UNTUK NYERI
}

\author{
CUPPING AS PAIN ALTERNATIVE THERAPY \\ Hanik Badriyah Hidayati, * Mohammad Hasan Machfoed, * Kuntoro, ** Soetojo, *** Budi Santoso, **** \\ Suroto, $* * * * *$ Budi Utomo $* * * * * *$
}

\begin{abstract}
Pain is still a world's problem. Current pain treatment is still unsatisfactory due to its chronicity and existing drugs' side effects. Due to dissatisfaction with the existing treatment, many patients are choosing a traditional therapy for their pain treatment. Cupping therapy is one of the traditional therapies that is widely used to relieve pain. Cupping therapy has been used in many countries in the world. Some of these countries have used cupping therapy as a pain treatment in hospitals. Neurologists are handling pain cases in their daily practice. Nearly $80 \%$ of patients come to the doctor with one of their complaint related to pain directly. The knowledge of cupping therapy for pain is important for the development of new therapies in order to solve the pain problems that so far have not reached a satisfactory level.
\end{abstract}

Keyword: Alternative therapy, cupping therapy, pain, pain problems

\section{ABSTRAK}

Nyeri masih merupakan masalah dunia. Pengobatan nyeri saat ini masih belum sampai tahap yang memuaskan terkait kronisitas dan efek samping obat yang ada. Akibat ketidakpuasan dengan pengobatan yang ada, banyak pasien yang memilih terapi tradisional untuk pengobatan nyerinya. Terapi bekam merupakan salah satu terapi tradisional yang banyak dipakai untuk meredakan keluhan nyeri. Terapi bekam telah dipakai di banyak negara di dunia. Sebagian negara tersebut telah menggunakan bekam sebagai terapi nyeri di rumah sakit. Bekam menurunkan nyeri melalui efek antinosiseptifnya, dengan cara stimulasi sistem saraf perifer dan menurunkan stres oksidatif. Studi terbaru menunjukkan bahwa terapi bekam basah dapat meningkatkan ekspresi ß-endorphin dan HSP70 keratinosit pada lokasi bekam. Dalam praktek sehari-hari dokter spesialis saraf menangani kasus nyeri. Hampir 80\% pasien datang ke dokter dengan disertai salah satu keluhan yang berkaitan dengan nyeri secara langsung. Pengetahuan tentang terapi bekam untuk nyeri penting diketahui untuk pengembangan terapi baru guna menyelesaikan permasalahan nyeri yang sampai saat ini belum sampai pada tahap yang memuaskan.

Kata kunci: Masalah nyeri, nyeri, terapi alternatif, terapi bekam

*Departemen Neurologi FK UNAIR/RSUD Dr. Soetomo, Surabaya; **Departemen Biostatistika dan Kependudukan FKM UNAIR, Surabaya; ***Departemen Urologi FK UNAIR/RSUD Dr. Soetomo, Surabaya; ****Departemen Obstetri Ginekologi FK UNAIR/ RSUD Dr. Soetomo, Surabaya; *****Departemen Neurologi FK UNS, Dr. Moewardi, Surakarta; ****** Departemen IKM-KP FK UNAIR, Surabaya. Korespondensi: hanikhidayati@yahoo.com.

\section{PENDAHULUAN}

Nyeri merupakan penyakit destruktif dan melemahkan, sehingga menjadi alasan terbanyak pasien mencari pertolongan medis maupun alternatif. ${ }^{1-3}$ Sekitar $80 \%$ pasien yang datang ke praktek umum akibat nyeri, terutama nyeri kronik. ${ }^{4}$ Di Amerika, jumlah total penderita nyeri kronik lebih banyak dari jumlah gabungan pasien penderita penyakit jantung, kanker, dan diabetes ${ }^{5}$ yang menghabiskan dana sangat besar. ${ }^{6}$ Adapun prevalensi nyeri kronik juga tinggi di Eropa, yaitu $25-30 \%$ penduduk. $^{5}$ Hasil penelitian multicentre di unit rawat jalan pada 14 rumah sakit pendidikan di seluruh Indonesia yang dilakukan oleh kelompok studi nyeri pada bulan Mei 2002, didapatkan sebanyak 4456 kasus nyeri adalah merupakan $25 \%$ dari total kunjungan pada bulan tersebut. Jumlah penderita laki-laki sebanyak 2.200 orang dan 2.256 orang perempuan. Kasus nyeri kepala 35,86\%, nyeri punggung bawah $18,3 \%$, sedangkan nyeri neuropatik yang merupakan gabungan nyeri neuropati diabetik, nyeri pasca-herpes, dan neuralgia trigeminal didapatkan sebanyak $9,5 \%{ }^{7}$

Kronisitas dan adanya efek samping obat analgesik membuat terapi nyeri belum mencapai tahap yang memuaskan, ${ }^{8-15}$ hingga banyak pasien berobat dengan pengobatan alternatif. Bekam merupakan salah satu pengobatan tradisional atau pengobatan rakyat di dunia yang digunakan sebagai terapi alternatif atau komplementer untuk mengobati banyak gangguan, termasuk nyeri. ${ }^{16-17}$ Baru-baru ini didapatkan bukti bahwa bekam efektif menurunkan nyeri pada berbagai kondisi. ${ }^{18}$ 
Sejak 30 tahun yang lalu, World Health Organization (WHO) telah mengembangkan pengobatan tradisional untuk melaksanakan slogan "kesehatan untuk semua" pada tahun 2000. Hal ini berdasarkan kurangnya akses sejumlah besar (hingga $80 \%$ ) orang untuk mendapatkan perawatan kesehatan primer di beberapa negara dan akibat ketidakpuasan atas perawatan kedokteran modern terkait kronisitas penyakit dan adanya efek samping dari obat kimiawi. ${ }^{19}$

Pengetahuan tentang bekam ini akan menambah khazanah pengobatan analgesik bagi dokter spesialis saraf yang berperan penting dalam mengobati nyeri. Penting untuk mengetahui bekam, yaitu tentang sejarah, pemanfaatannya, dan efek samping penggunaannya, mengingat terapi ini banyak dilakukan oleh sebagian besar masyarakat Indonesia, bahkan masyarakat dunia.

\section{PEMBAHASAN}

\section{Sejarah Bekam}

Bekam dikenal dengan berbagai istilah seperti: canduk, canthuk, kop, dan lainnya. Di dunia barat bekam disebut sebagai cupping method atau cupping therapy. Orang Inggris Tengah menyebut bekam dengan kata ventusynge. Kata ini berasal dari Perancis ventoúza. Dalam bahasa Yunani disebut dengan kata $\beta \varepsilon v \tau o v ́ \zeta \alpha{ }^{20}$

Bekam merupakan pengobatan rakyat atau pengobatan tradisional yang digunakan sebagai salah satu jenis terapi komplementer atau alternatif untuk pengobatan nyeri di seluruh dunia, ${ }^{21-23}$ antara lain: di Mesir, Korea, Taiwan, Italia, Jepang, Amerika, Perancis, India, Belanda, Inggris, Arab, China, Vietnam, Persia, dan sebagainya. ${ }^{16,20,23-26}$ Korea telah menggunakan terapi bekam secara resmi di rumah sakit. Romawi dan Yunani di masa lalu juga telah menggunakan bekam sebagai salah satu terapi medis mereka. ${ }^{27}$ Dari Yunani bekam menyebar ke Amerika dan Eropa. ${ }^{20,28}$ Kebanyakan bekam dilakukan di Asia dan pertengahan negara barat, baik di rumah maupun di tempat praktek. ${ }^{18,20}$

Bekam merupakan salah satu intervensi medis tertua yang dipercaya ada sejak 3000 sebelum masehi. Catatan paling awal tentang bekam adalah dalam
Ebers Papyrus, salah satu buku teks kedokteran tertua di dunia. Buku ini menuliskan bahwa bekam telah ada di Mesir pada tahun 1.550 tahun sebelum masehi (SM) dengan mekanisme kerja membuang zat asing dari dalam tubuh. ${ }^{28}$

Terapi bekam juga telah digunakan di Cina dan Afrika beberapa ribu tahun lalu. ${ }^{20}$ Para arkeolog menemukan bukti bahwa bekam telah dilakukan di Cina 1000 SM. Literatur-literatur Cina pada abad kedua membuktikan penggunaan bekam disana, serta artefak dari Romawi dan Yunani menunjukkan bekam telah digunakan di negara-negara barat. ${ }^{27} \mathrm{Hal}$ ini dapat ditemukan dalam tulisan Hippocrates (377 SM-460 Masehi), bapak kedokteran modern.

Pada tahun 400 SM, Hippocrates telah menggunakan bekam untuk penyakit dalam dan gangguan struktural, seperti angina, menstruasi, dan gangguan lainnya. Hippocrates juga menulis tentang dua bentuk bekam, yaitu bekam kering dan bekam basah. Meskipun telah mempraktekkan bekam basah, Hippocrates lebih menganjurkan bekam kering karena teknik bekam kering dilakukan secara lembut dan lebih aman. Metode ini kemudian menyebar ke kedokteran di peradaban Asia dan Eropa. ${ }^{19}$

Alat kop bekam pada jaman dahulu menggunakan berbagai sumber daya alam seperti kerang, tanduk hewan berongga seperti ujung tanduk kerbau atau tulang yang berlubang (Gambar 1a dan 1b). Tekanan negatif dibuat dengan menyedot udara keluar dari ujung tanduk dengan menggunakan mulut. ${ }^{19-20}$ Kop bekam yang lebih modern berupa bambu, gelas, atau cangkir. Pada penggunaan kop bekam dari bambu, gerabah dan cangkir kaca, pengeluran udara dilakukan dengan api yang menyala. $^{20}$

Bekam di Eropa dilakukan oleh dokter terkenal, seperti Galen (131-200 SM), Paracelsus (14931541), dan Ambroise Pare (1509-1590). Wellcome Institute Library London menyimpan gambar salah satu tentara yang dibekam salah satu lengannya saat peperangan antara Prancis dengan Jerman tahun 1820 (Gambar 2) dan gambar seorang dokter bedah yang menerapkan bekam basah pada punggung salah satu pasiennya (Gambar 3a). ${ }^{20}$ 


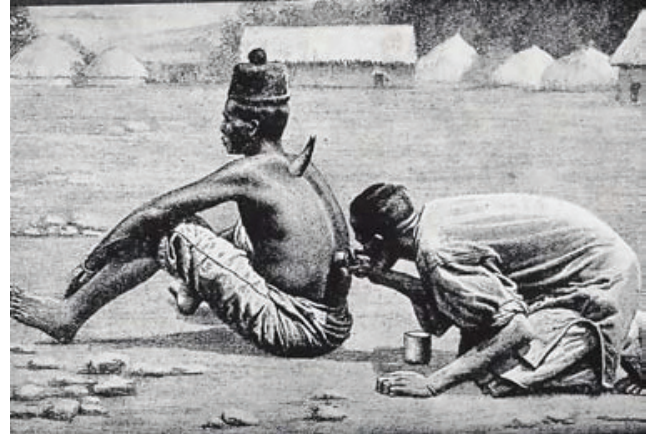

$1 \mathrm{a}$

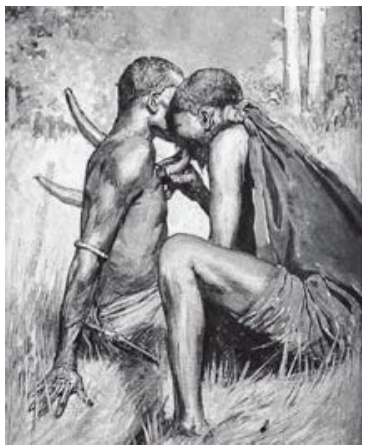

$1 \mathrm{~b}$

Gambar 1. Penerapan Bekam dengan Menggunakan Tanduk Kerbau

1a dan b seorang terapis atau dukun Afrika sedang menerapkan teknik bekam pada pasien dengan menggunakan tanduk hewan, termasuk mengeluarkan darah pasien ke permukaan tubuh. ${ }^{20}$

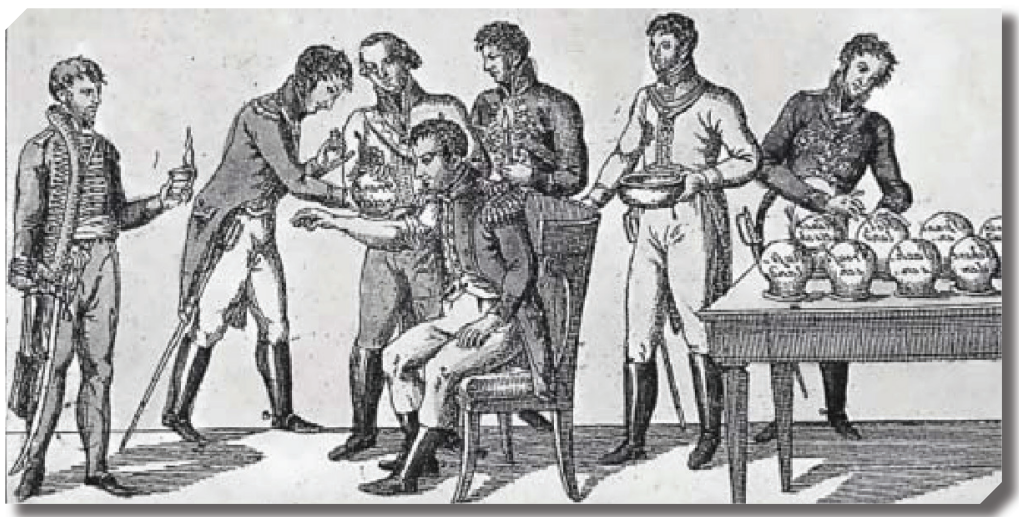

Gambar 2. Bekam pada Lengan Tentara saat Perang antara Prancis dengan Jerman Tahun $\mathbf{1 8 2 0}^{20}$

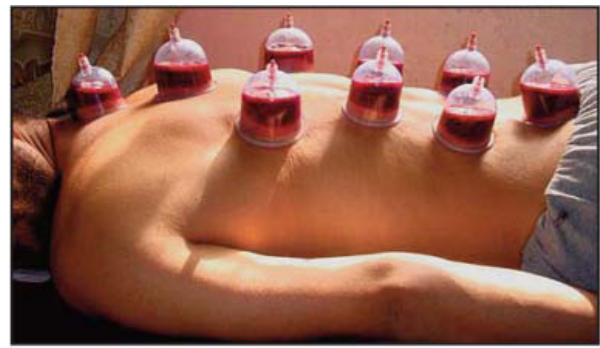

$3 \mathrm{~b}$

Gambar 3. Bekam pada Punggung

3a. Seorang dokter bedah menerapkan bekam basah pada punggung salah satu pasiennya; ${ }^{20} 3 \mathrm{~b}$. Penempatan kop di kulit punggung pada bekam basah, darah tampak keluar ke dalam kop. ${ }^{29}$

\section{Alat dan Metode Bekam}

Alat bekam antara lain scalpel steril atau pisau bedah ukuran 15-22 gauge yang digunakan untuk menoreh kulit pada prosedur bekam basah, 6-12 kop plastik, pompa penyedot (manual atau elektrik), kertas tisu, lap, alat antiseptik seperti alkohol, bola kapas, dan minyak zaitun (untuk mempermudah gerakan kop). ${ }^{19-20,26-30}$
Bekam pada pengobatan tradisional Cina ada 10 macam, yaitu: bekam basah, bekam air, bekam kombinasi, bekam yang ditahan, bekam seluncur, bekam gerak, bekam obat, bekam cepat, bekam air, dan bekam jarum. ${ }^{20,27}$ Namun secara umum bekam dibagi menjadi dua macam, yaitu: bekam kering dan bekam basah. Pendekatan keduanya sama, yaitu menstimulasi kulit dengan meletakkan mangkuk yang diberi tekanan negatif. 
Pada bekam kering dilakukan pengekopan pada kulit yang intak, sedangkan pada bekam basah dilakukan torehan kulit dan penarikan darah keluar (Gambar 3b). Metode bekam basah ada yang menggunakan metode cupping-puncturingcupping (CPC) dan ada yang menggunakan metode puncturing-cupping (PC). Metode CPC disebutkan lebih unggul dibandingkan dengan PC. ${ }^{31}$

Titik bekam berada di permukaan kulit, bisa merupakan titik akupunktur, akupresur, refleksi, titik tung, tho' dan sebagainya. Titik bekam yang sedang berkembang di Indonesia adalah di titik meredian akupuntur dan titik bekam Nabi atau Prophet Potent Point. ${ }^{32}$ Secara umum kop bekam diletakkan pada titik akupunktur atau titik nyeri. ${ }^{21}$

\section{Bekam sebagai Terapi Alternatif Nyeri}

Definisi nyeri menurut The International Association for the Study of Pain (IASP) adalah pengalaman sensorik dan emosional yang tidak menyenangkan terkait dengan kerusakan jaringan, baik aktual maupun potensial, atau yang digambarkan dalam bentuk kerusakan tersebut. ${ }^{8,27-28}$ Kualitas hidup pasien bisa terganggu akibat nyeri, bisa berupa gangguan dalam hal pekerjaan, hubungan sosial, tidur, hobi, proses kognitif, maupun mood. ${ }^{29-30}$

Bekam telah banyak dipakai untuk meredakan nyeri pada beberapa gangguan seperti: nyeri muskuloskeletal (termasuk sprain, strain traumatik dan pasca - fraktur), gejala terkait herpes zoster, nyeri punggung bawah dan nyeri lumbal (lumbago) seperti herniasi diskus lumbal, nyeri skeletal, nyeri leher yang salah satunya spondilosis servikal, nyeri bahu, migren dan nyeri kepala lain, dismenorea, atralgia sederhana, gout arthritis, rheumatoid arthritis, chronic fatigue syndrome, fibromialgia, osteoartritis lutut, carpal tunnel syndrome (CTS), plantar fasciitis, brachialgia paraesthetica nocturna, trigeminal neuralgia, fatigue pada atlet, dan sebagainya. $2,4,16-17,20-21,31$

Saat ini bekam telah banyak diteliti (Tabel 1). Sebuah Randomized Controlled Trial (RCT) membandingkan efek bekam kering pada nyeri kanker dengan terapi obat konvensional mendapatkan bahwa bekam memberikan efek yang menguntungkan setelah intervensi 3 hari (RR 67\% dibanding 43\%, $<<0,05)$. Randomized Controlled
Trial lain membandingkan bekam kering dengan obat antiinflamasi nonsteroid pada nyeri punggung bawah nonspesifik, didapatkan perbedaan yang signifikan pada penghilang nyeri dengan skala visual analog score (VAS) setelah pengobatan (MD 22,8 dari 100mm VAS; IK 95\%, 11,4-34,2, p<0,001).

Terdapat pula RCT tentang penurunan rasa nyeri setelah periode intervensi bekam basah dibandingkan dengan analgesik pada trigeminal neuralgia akut; didapatkan RR 93\% berbanding 47\% secara bermakna $(\mathrm{p}<0,01)$. Randomized Controlled Trial lain menguji bekam basah ditambah perawatan biasa untuk menurunkan nyeri dibandingkan dengan perawatan biasa pada nyeri punggung bawah nonspesifik. Terdapat perbedaan yang signifikan menggunakan McGill Pain Questionnaire pada 3 bulan setelah tiga sesi perawatan Mean Difference (MD) 2,2 dari 6 poin penunjuk intensitas nyeri; IK $95 \%, 1,7-2,6, \mathrm{p}<0,01)$.

Randomized Controlled Trial kelima melaporkan bahwa satu sesi bekam basah ditambah perawatan biasa secara signifikan menurunkan rasa nyeri selama seminggu dibandingkan dengan perawatan biasa saja pada pasien dengan brachialgia paraesthetica nocturna/BPN (skor MD 1,6 dari 10 poin, IK 95\%, 0,13-3,07, $\mathrm{p}=0,03$ ).

Randomized controlled lebih lanjut keenam menunjukkan adanya efek yang menguntungkan dari satu sesi bekam basah pada pengurangan nyeri dibandingkan dengan bantal panas pada pasien dengan BPN pada 7 hari setelah pengobatan (MD $22,9$, VAS 100mm; IK 95\%, 10,5-35,3, $\mathrm{p}<0,001)$. Randomized Controlled Trial adalah tentang penurunan rasa nyeri pada bekam basah yang ditambah dengan obat konvensional dibandingkan dengan obat konvensional saja pada pasien dengan herpes zoster, pada RCT ini bekam basah gagal untuk menunjukkan efek menguntungkan setelah periode intervensi (RR 100\% berbanding $88 \%, \mathrm{p}=0,065){ }^{38}$

\section{Mekanisme Kerja Analgesik Bekam \\ Menurut Teori Pengobatan China}

Praktisi terapi bekam pada Traditional Chinese Medicine (TCM) Therapy meyakini bahwa penyakit disebabkan oleh stagnasi atau terblokirnya energi kehidupan yang vital (Qi). Mereka mempercayai 
Tabel 1. Tabel Ringkasan RCTPercobaan Klinis Bekam untuk Kondisi Nyeri ${ }^{38}$

\begin{tabular}{|c|c|c|c|c|c|c|c|}
\hline $\begin{array}{l}\text { Penulis } \\
\text { Utama, } \\
\text { Negara }\end{array}$ & $\begin{array}{l}\text { Jumlah } \\
\text { Sampel }\end{array}$ & $\begin{array}{l}\text { Intervensi } \\
\text { (Regimen) }\end{array}$ & Kontrol (Regimen) & $\begin{array}{l}\text { Total } \\
\text { Sesi }\end{array}$ & $\begin{array}{l}\text { Nyeri Terkait } \\
\text { Luaran } \\
\text { Utama }\end{array}$ & Hasil Utama & $\begin{array}{c}\text { Waktu } \\
\text { Pengukuran }\end{array}$ \\
\hline $\begin{array}{l}\text { Huang } \\
\text { (2006), } \\
\text { China }\end{array}$ & $\begin{array}{c}\text { 60/nyeri } \\
\text { kanker/ } \\
5-17 \text { bulan }\end{array}$ & $\begin{array}{l}\text { (A) Bekam } \\
\text { kering (lama: } 5 \\
\text { menit, ulang lagi } \\
\text { selama: } 10-15 \\
\text { menit, sekali } \\
\text { sehari selama } 3 \\
\text { hari, } \mathrm{n}=30 \text { ) }\end{array}$ & $\begin{array}{l}\text { (B) Opioid (propoxy- } \\
\text { phene napsylate dan } \\
\text { paracetamol, dua } \\
\text { tablet, } 3 \text { kali kali } \\
\text { sehari selama } 3 \text { hari, } \\
\mathrm{n}=30 \text { ) }\end{array}$ & 3 & \begin{tabular}{lr}
\multicolumn{2}{l}{$(1)$ Responserate } \\
$(\%$ & reduksi \\
nyeri & $\geq 70 \%)$ \\
$(2)$ & Durasi \\
bebas & nyeri \\
$(\mathrm{h})$ & \\
\end{tabular} & 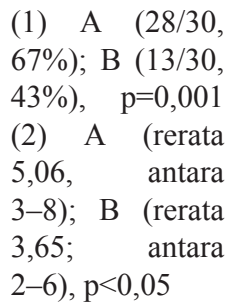 & $\begin{array}{l}\text { Baseline: } \\
\mathrm{s} \text { e b e } 1 \mathrm{u} \mathrm{m} \\
\text { intervensi } \\
\text { Post: setelah } \\
\text { intervensi } \\
\text { final }\end{array}$ \\
\hline $\begin{array}{l}\text { Hong } \\
\text { (2006), } \\
\text { China }\end{array}$ & $\begin{array}{l}\text { 70/LBP } \\
\text { non- } \\
\text { spesifik/1 } \\
\text { minggu } \\
\text { sampai } 3,1 \\
\text { tahun }\end{array}$ & $\begin{array}{l}\text { (A) Bekam } \\
\text { kering (bekam } \\
\text { seluncur, } 5 \\
\text { menit, 1/2 hari } \\
\text { selama 11 hari, } \\
\text { n=37), tidak ada } \\
\text { tambahan }\end{array}$ & $\begin{array}{l}\text { (B) NSAIDs } \\
\text { (dexibupro-fen; } \\
0,15 \mathrm{~g} ; \text { tiga kali } \\
\text { sehari selama } 12 \\
\text { hari, } \mathrm{n}=33 \text { ) }\end{array}$ & 6 & $\begin{array}{l}(1) \quad \text { Nyeri } \\
\text { dengan VAS } \\
(100 \mathrm{~mm}) \quad(2) \\
\text { Response rate } \\
(\% \text { perubahan } \\
\text { VAS } \geq 80 \%)\end{array}$ & $\begin{array}{l}(1) \quad \text { Perbedaan } \\
\text { rerata } 22,8 \text { (IK } \\
95 \%, \quad 11,4- \\
34,2), \mathrm{p}<0,0001 \\
\text { mendukung (A) } \\
(2) \text { A }(21 / 37, \\
57 \%) ; \mathrm{B}(9 / 33, \\
27 \%), \mathrm{p}=0,03\end{array}$ & $\begin{array}{l}\text { Baseline: } \\
\text { s e b e } 1 \mathrm{u} \mathrm{m} \\
\text { intervensi } \\
\text { Post: setelah } \\
\text { intervensi } \\
\text { final }\end{array}$ \\
\hline $\begin{array}{l}\text { Zhang } \\
\text { (1997), } \\
\text { China }\end{array}$ & $\begin{array}{l}45 / \\
\text { neuralgia } \\
\text { trigeminal } \\
\text { akut/6 hari } \\
\text { sampai } 4 \\
\text { tahun }\end{array}$ & $\begin{array}{l}\text { (A) Bekam } \\
\text { basah (15 menit, } \\
\text { sekali sehari } \\
\text { selama } 6 \text { hari dan } \\
\text { kemudian sekali } \\
\text { setiap selang } 1 \\
\text { hari selama tiga } \\
\text { sesi, } n=30) \text {, tidak } \\
\text { ada tambahan }\end{array}$ & $\begin{array}{l}\text { (B) Analgesik (AP- } \\
23750 \mathrm{mg} \text { (IM, hanya } \\
\text { saat hari pertama) } \\
\text { dan kemudian } 60 \mathrm{mg} \\
\text { (oral, tiga kali sehari } \\
\text { selama } 12 \text { hari, } \\
\mathrm{n}=15 \text { ) }\end{array}$ & 9 & Response rate & $\begin{array}{l}\text { A }(28 / 30,93 \%) \\
B(7 / 15, \\
p=0,02\end{array}$ & $\begin{array}{l}\text { Baseline: } \\
\text { s e b e } 1 \mathrm{u} \mathrm{m} \\
\text { intervensi } \\
\text { Post: setelah } \\
\text { intervensi } \\
\text { final }\end{array}$ \\
\hline $\begin{array}{l}\text { Farhadi } \\
\text { (2009), } \\
\text { Iran }\end{array}$ & $\begin{array}{l}\text { 98/LBP } \\
\text { non- } \\
\text { spesifik/ } \geq 4 \\
\text { minggu }\end{array}$ & $\begin{array}{l}\text { (A) } \\
\text { Bekam basah ( } 20 \\
\text { menit, tiga tahap, } \\
\text { interval } 3 \text { hari, } \\
n=48) \text {, plus (B) }\end{array}$ & $\begin{array}{l}\text { (B) Perawatan biasa } \\
(\mathrm{n}=50)\end{array}$ & 3 & $\begin{array}{l}\text { PPI dari MPQ } \\
\text { (skala Likert } \\
\text { 6-poin) }\end{array}$ & $\begin{array}{l}\mathrm{P} \text { e } \mathrm{r} \text { b e d a a } \mathrm{n} \\
\text { rerata } 2,2 \text { points } \\
(\mathrm{IK} \quad 95 \%, \quad 1,7- \\
2,6), \quad \mathrm{p}<0,01 \\
\text { mendukung } \mathrm{A}\end{array}$ & $\begin{array}{l}\text { Baseline: } \\
\text { sebelum } \\
\text { memulai } \\
\text { percobaan } \\
\text { Post: } 3 \text { bulan } \\
\text { setelah }\end{array}$ \\
\hline $\begin{array}{l}\text { Ludtke } \\
(2006) \text {, } \\
\text { Germany }\end{array}$ & $\begin{array}{l}\text { 20/BPN/ } \\
\text { tidak } \\
\text { dilaporkan }\end{array}$ & $\begin{array}{l}\text { (A)Bekam basah } \\
(10 \text { menit, sekali, } \\
n=10) \text {, ditambah } \\
\text { (B) }\end{array}$ & $\begin{array}{l}\text { (B) Perawatan } \\
\text { biasa (analgesik, } \\
\text { fisioterapi, perawatan } \\
\text { psikologis, terapi } \\
\text { musik, } \mathrm{n}=10)\end{array}$ & 1 & $\begin{array}{lr}\text { Nyeri } & \text { pada } \\
\text { skor brakialgia } \\
\text { (NAS, skala } \\
\text { Likert } & 10- \\
\text { poin) } & \end{array}$ & 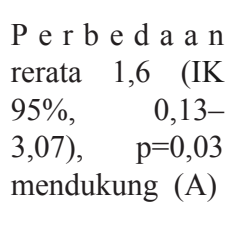 & \\
\hline $\begin{array}{l}\text { Michalsen } \\
(2007), \\
\text { Germany }\end{array}$ & $\begin{array}{l}\text { 52/BPN/ } \\
\text { tidak } \\
\text { dilaporkan }\end{array}$ & $\begin{array}{l}\text { (A)Bekam basah } \\
(10 \text { menit, sekali, } \\
n=26) \text {, ditambah } \\
\text { (B) }\end{array}$ & $\begin{array}{l}\text { (B)Bantal panas } \\
(\mathrm{n}=26)\end{array}$ & 1 & 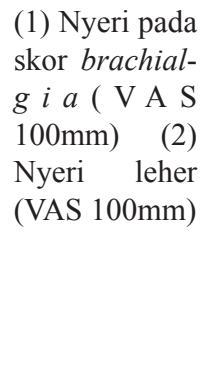 & 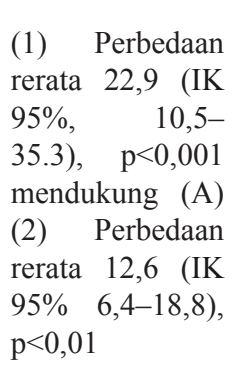 & \\
\hline $\begin{array}{l}\text { Xu (2004), } \\
\text { China }\end{array}$ & $\begin{array}{l}\text { 80/Her-pes } \\
\text { zoster/ 1-3 } \\
\text { hari }\end{array}$ & $\begin{array}{l}\text { (A) } \\
\text { Bekam basah } \\
(15 \text { menit, sekali } \\
\text { sehari selama } \\
7 \quad \text { hari,n=40), } \\
\text { ditambah }(\mathrm{B})\end{array}$ & $\begin{array}{lr}\text { (B) Anti } & \text { viral } \\
\text { (aciclovir 0,5g+5\% } \\
\text { DW 250ml (IV), } \\
\text { ditambah } & \text { krim } \\
\text { aciclovir (pemakaian } \\
\text { luar), 2 kali sehari } \\
\text { selama } 7 \text { hari, } \mathrm{n}=40 \text { ) }\end{array}$ & 7 & $\begin{array}{l}\text { Response rate } \\
(\% \text { derajat } \\
\text { nyeri } \geq 60 \%)\end{array}$ & $\begin{array}{l}40 / 40, \quad 100 \%) \\
\mathrm{B}(35 / 40,88 \%) \\
\mathrm{p}=0,065\end{array}$ & \\
\hline
\end{tabular}

RCT: Randomized Controlled Trial; LBP: low back pain; BPN: brachialgia paraesthetica nocturna; MPQ: McGill Pain Questionnaire; NAS: Numeric Analogue Scale; NSAID: non-steroidal anti-inflammatory drug; PPI: Present Pain Intensity;VAS: Visual Analogue Scale; IK: interval kepercayaan. 
bahwa terapi bekam bekerja melalui terbukanya blokade Qi dan pengembalian keseimbangan aliran Qi secara benar. Menurut seksologi medis tradisional China, perempuan mengeluarkan Yin (Qi perempuan) dan laki-laki mengeluarkan Yang (Qi laki-laki). Yin akan menerima Yang, sementara Yang akan menerima Yin. Terapi bekam dapat membuang udara, dingin, kelembaban, dan darah yang stagnan, khususnya jika dikombinasi dengan terapi akupunktur. Menurut hukum biologis Arndt-Schulz, akupunktur laser yang dikombinasi dengan terapi bekam pada daerah yang nyeri dianggap mampu memfasilitasi aliran Qi pada daerah meridian. ${ }^{16}$

Beberapa ilmuwan barat mengikuti teori yang disampaikan oleh Ilkay Chirali dalam bukunya yang berjudul Traditional Chinese Medicine Cupping Therapy, bahwa mekanisme kerja bekam sebagai analgesik adalah dengan menginduksi perubahan Qi (sumber energi), Xu (defisiensi darah), Wei Qi (defisiensi energi), dan konsep lain menurut teori pengobatan China. ${ }^{16}$ Efek utama bekam adalah memicu presipitasi aliran darah dan Qi serta membuang stasis darah dan sampah tubuh. ${ }^{4}$

\section{Menurut Teori Taibah}

Prosedur bekam hijamah terdiri atas beberapa langkah, yaitu: pengekopan pertama, penorehan kulit, dan diikuti oleh pengekopan kedua. Menurut teori Taibah mekanisme kerja efek analgesik bekam pada pengekopan pertama (Gambar 4) adalah melalui dilusi zat kimia, mediator inflamasi, dan zat nosiseptif. Tekanan negatif kop pada permukaan kulit akan menyebabkan kulit terangkat, peningkatan filtrasi kapiler, dan pengumpulan cairan interstisial. Retensi cairan di dalam kulit yang terangkat akan menyebabkan zat kimia, mediator inflamasi, dan zat nosiseptif menjadi terdilusi sehingga nyeri akan menurun. ${ }^{16}$

Pada penorehan kulit bekam hijamah (Gambar 5) sejumlah kecil darah dikeluarkan untuk mengeluarkan toksin. ${ }^{20}$ Penorehan kulit akan meningkatkan imunitas (innate dan acquired) dan membuka sawar kulit. Pembukaan sawar kulit dan adanya tekanan kop akan menyebabkan terjadinya hemolisis sel darah merah tua, meningkatkan ekskresi cairan interstisial yang tercampur dengan sampah,

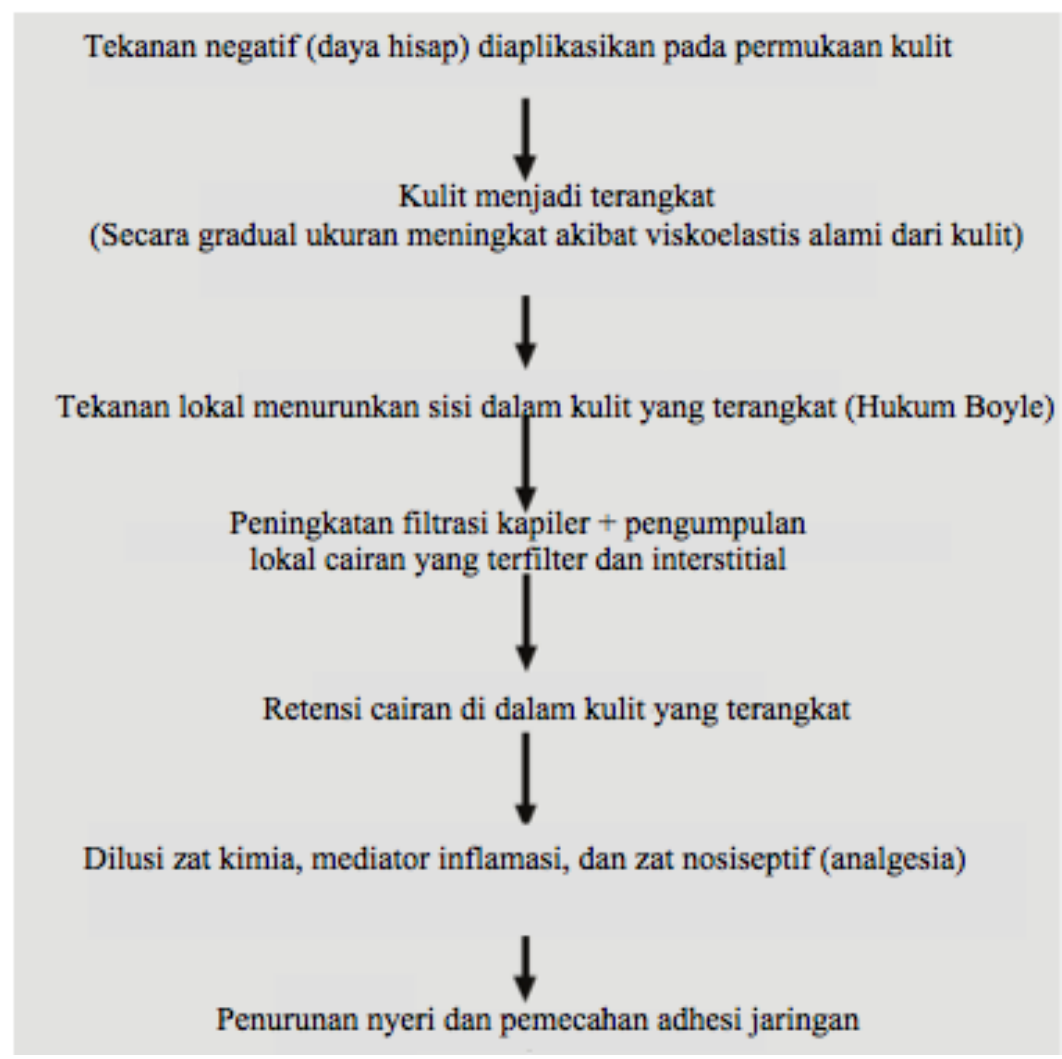

Gambar 4. Teori Taibah: Mekanisme Bekam Kering

Menjelaskan langkah pertama Al Hijamah (terapi bekam kering). ${ }^{22}$ 


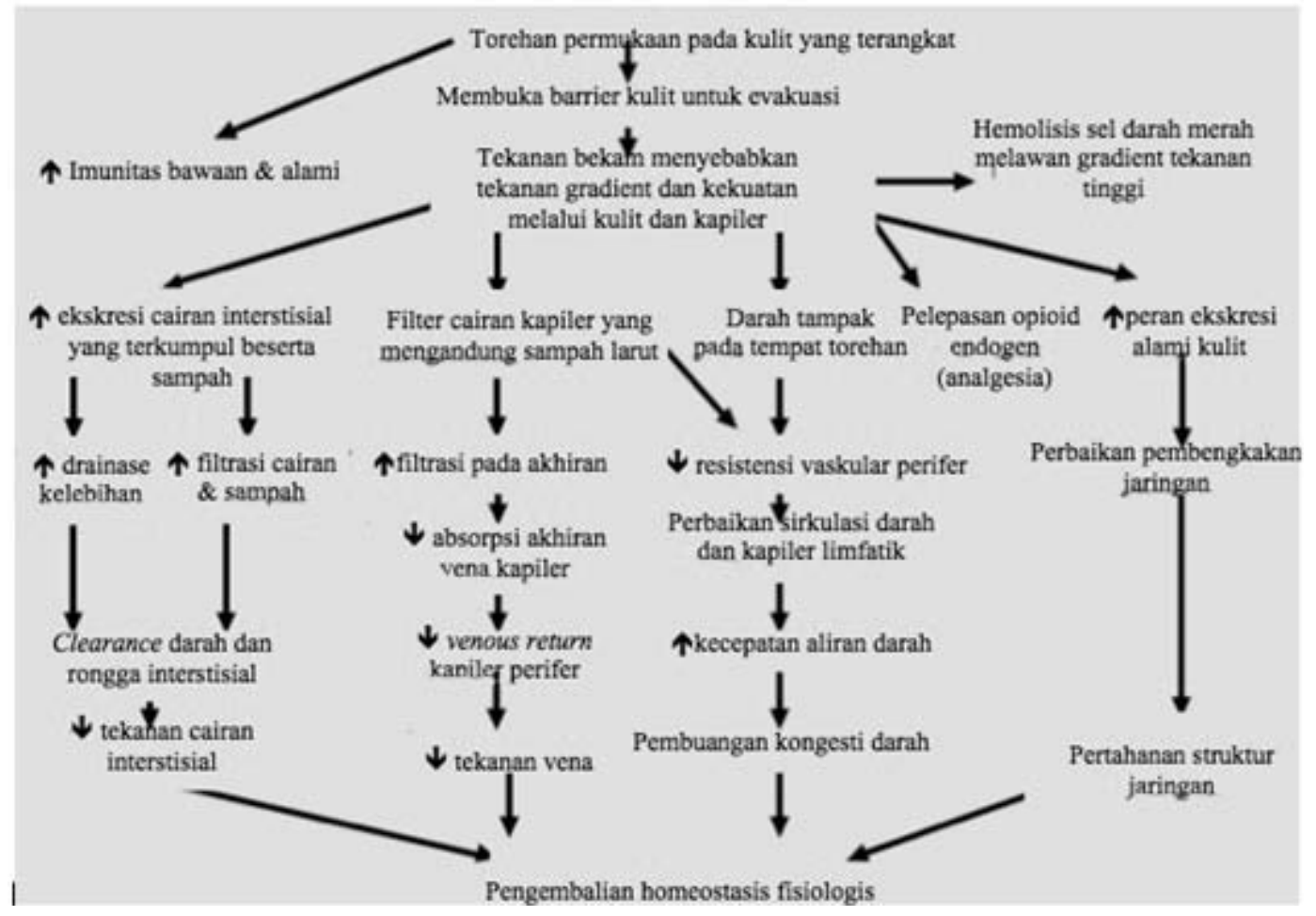

Gambar 5. Teori Taibah: Mekanisme Bekam Basah

Menjelaskan langkah ke-dua Al Hijamah (terapi bekam basah). ${ }^{22}$

menyaring cairan kapiler yang mengandung sampah larut, melepaskan opioid endogen, meningkatkan peran sekretorik kulit dan menyebabkan darah nampak pada tempat torehan. Semua hal tersebut pada akhirnya akan mengembalikan homeostasis tubuh. ${ }^{16}$

\section{Menurut Teori Hong dan Gao dkk}

Hong dkk melaporkan bahwa terapi bekam melalui tekanan negatif kop akan menyebabkan terjadinya perubahan spesifik pada struktur jaringan lokal. Peregangan saraf dan otot menyebabkan terjadinya peningkatan sirkulasi darah dan autohemolisis. Mekanisme bekam yang diajukan oleh Hong dkk mungkin bisa diterima ketika menyebutkan bahwa tekanan negatif lokal dapat memengaruhi struktur jaringan dan meningkatkan sirkulasi darah, namun tidak cukup untuk menjelaskan keuntungan bekam dalam mengobati migren, CTS, nyeri kepala, dan sebagainya. Sebagai tambahan, apakah autohemolisis menguntungkan untuk menjelaskan penyakit yang disebutkan sebelumnya? Jawabannya adalah tidak. Mekanisme Hong hanya secara parsial berhasil menjelaskan efek terapeutik terapi bekam. ${ }^{16}$

\section{Menurut Teori Gao dkk}

Gao dkk menduga bahwa peletakan bekam pada titik kulit yang terpilih akan menghasilkan hiperemia atau hemostasis yang akan menghasilkan efek terapeutik. Dugaan Gao dkk ini terlihat tidak cukup menjelaskan efek menguntungkan terapi bekam dalam terapi RA, CTS, dan lain-lain. ${ }^{16}$

\section{Efek Samping Terapi Bekam}

Efek samping bekam minimal. Pada 135 penelitian RCTs tidak ada yang melaporkan efek samping yang serius. ${ }^{21}$ Sebuah tinjauan studi oleh Cao dan kawan-kawan yang termasuk semua studi klinis (yang diterbitkan antara tahun 1959 sampai 2008, termasuk 73 RCT, 22 Clinical Controlled Trials, 373 seri kasus, dan 82 laporan kasus) dilaporkan tidak ada efek samping serius yang dilaporkan dalam studi tersebut. ${ }^{3}$

Jurnal lain menyebutkan bekam memiliki efek samping seperti: eritema multiforme, herpes simpleks, anemia, pigmentasi kulit, factitial panniculitis, defisiensi besi, dan abses epidural servikal. Praktisi dan pasien diharapkan tetap berhati-hati agar tetap 
mendapatkan keamanan terapi bekam. ${ }^{21}$

\section{KESIMPULAN}

Sampai saat ini nyeri masih merupakan masalah bersama karena masih belum sampai tahap yang memuaskan. Bekam merupakan salah satu pilihan terapi alternatif untuk kondisi nyeri. Beberapa studi RCT mendukung tentang pemakaian bekam sebagai terapi alternatif untuk menurunkan nyeri yang menunjukkan bahwa bekam memberikan efek menguntungkan menurunkan nyeri secara signifikan pada nyeri kanker, nyeri punggung bawah nonspesifik, trigeminal neuralgia akut, namun gagal menunjukkan efek menguntungkan pada pasien dengan herpes zoster setelah periode intervensi.

Meskipun studi RCT telah menunjukkan efek menguntungkan bekam dalam menurunkan nyeri, namun mekanismenya masih belum jelas. Beberapa teori seperti Teori Taibah, teori Hong, dan teori Gao mencoba menjelaskan tentang mekanisme bekam, namun masih belum menjelaskan secara keseluruhan sehingga masih diperlukan penelitian lebih lanjut untuk memperjelas mekanisme bekam dalam menurunkan nyeri. Optimalisasi peran bekam dan upaya untuk meminimalisir efek samping yang diakibatkan oleh bekam juga perlu dilakukan penelitian lebih lanjut.

\section{DAFTAR PUSTAKA}

1. Rosenblum A, Marsch LA, Joseph H, Portenoy RK. Opioids treatment of chronic pain: controversies current status and future directions. NIH Public Access. 2009;16(5):405-16.

2. Okuse K. Pain signalling pathways: from cytokines to ion channels. Int J Biochem Cell Biol. 2007;39(3):4906.

3. Yousuf MS, Kerr BJ. The role of regulatory transporters in neuropathic pain. Adv Pharmacol. 2016;75:245-71.

4. Cao H, Li X, Yan X, Wang NS, Bensoussan A, Liu J. Cupping therapy for acute and chronic pain management: a systematic review of randomized clinical trials. J Tradit Chinese Med Sci. 2014;1(1):4961.

5. Cohen SP, Mao J. Neuropathic pain: mechanisms and their clinical implications. BMJ. 2014;348:f7656.

6. Mehta N, Inturrisi CE, Horn SD, Witkin LR. Using chronic pain outcomes data to improve outcomes. Anesthesiol Clin. 2016;34(2):395-408.
7. Hasbar AIM. Karakteristik pasien rawat jalan dengan keluhan nyeri di Puskesmas Batua Makassar pada bulan Februari 2017. Optimization Software[serialonline].2017 [diunduh 17 Februari 2017]. Tersedia dari:Balesio.

8. Rohacs T. Advances in biological regulation phosphoinositide signaling in somatosensory neurons. Adv Biol Regul. 2016;61:2-16.

9. Backryd E, Ghafouri B, Larsson B, Gerdle B. Plasma pro-inflammatory markers in chronic neuropathic pain: a multivariate, comparative, cross-sectional pilot study. Scand J Pain. 2016;10:1-5.

10. Salvat E, Yalcin I, Barrot M. Review antidepressants and gabapentinoids in neuropathic pain. Neuroscience. 2016;338:183-206.

11. Sagheddu C, Aroni S, De-Felice M, Lecca S, Luchicchi A, Melis M, dkk. Neuropharmacology enhanced serotonin and mesolimbic dopamine transmissions in a rat model of neuropathic pain. Neuropharmacology. 2015;97:383-93.

12. Khan H, Eto B, De-Feo V, Gilani AU. Evidence based alternative medicines in pain management. Evid Based Complement Alternat Med. 2015;2015:12.

13. Gangadharan V, Kuner R. Pain hypersensitivity mechanisms at a glance. Dis Model Mech. 2013;6(4):889-95.

14. Forde G, Duarte RA, Rosen N. Managing chronic headache disorders. Med Clin North Am. 2016;100(1):117-41.

15. Hidayati HB, Kuntoro, Machfoed MH, Sugianto P, Khotib J, Ardianto C. Pengukuran tingkah laku pada model nyeri neuropatik perifer: tikus dengan CCI (chronic constriction injury). Neurona. 2018;35:20913.

16. Cao H, Han M, Zhu X, Liu J. An overview of systematic reviews of clinical evidence for cupping therapy. J Tradit Chinese Med Sci. 2015;2(1):3-10.

17. Mehta P, Dhapte V. Cupping therapy: a prudent remedy for a plethora of medical ailments. J Tradit Complement Med. 2015;5(3):127-34.

18. Arslan M, Gokgoz N, Dane S. The effect of traditional wet cupping on shoulder pain and neck pain: a pilot study. Complement Ther Clin Pract. 2016;23:30-3.

19. Reza M, Mahdavi V, Ghazanfari T. Evaluation of the effects of traditional cupping on the biochemical, hematological and immunological factors of human venous blood. A Compend Essays Altern Ther: Croatia: InTech.2012:2012:67-88.

20. Chirali IZ. Traditional Chinese medicine cupping therapy. Edisi ke-3. London: Elsevier Ltd; 2014.

21. Tagil SM, Celik HT, Ciftci S, Kazanci FH, Arslan M, Erdamar N, dkk. Wet-cupping removes oxidants and 
decreases oxidative stress. Complement Ther Med. 2014;22(6):1032-6.

22. El Sayed S, Mahmoud H, Nabo M. Alternative and integrative medicine medical and scientific bases of wet cupping therapy (Al-Hijamah): in light of modern medicine and prophetic medicine. Altern Integ Med. 2013;2(3):1-16.

23. Mahmoud HS, Abou-El-Naga M, Ayoub N, Omar A, El-ghazzawy HA, Fathy YM. Alternative \& integrative medicine anatomical sites for practicing wet cupping therapy (al-Hijamah ): in light of modern medicine and prophetic medicine. Altern Integ Med. 2013;2(8):1-30.

24. Tabatabaee A, Zarei M, Javadi SA, Mohammadpour A. The effects of wet-cupping on intensity of headache in migraine sufferers. JJCDC. 2014;3(2):1-12.

25. Mulla G, Ahmed J, Ghawte SA, Ajmal KT, Fatema A. A comparative study of hematological profile of cupping (Hijamah ) versus venous blood. IJHS.2015;2:101-7.

26. Sajid MI. Hijama therapy (wet cupping)-its potential use to complement British healthcare in practice, understanding, evidence and regulation. Complement Ther Clin Pract. 2016;23:9-13.

27. Kim T, Hyung K, Choi J, Soo M. Adverse events related to cupping therapy in studies conducted in Korea: a systematic review. Eur J Integr Med. 2014;6(4):434-40.

28. Rozenfeld E, Kalichman L. New is the well-forgotten old: the use of dry cupping in musculoskeletal medicine. J Bodyw Mov Ther. 2016;20(1):173-8.

29. Qasim Ali Al-Rubaye K. The clinical and histological skin changes after the cupping therapy (Al-Hijamah). J Turkish Acad Dermatology. 2012;6(1):1-7.
30. El-Domyati M, Saleh F. Evaluation of cupping therapy in some dermatoses. Egypt Dermatology Online J. 2013;9(1):1-15.

31. Mohamed S, Sayed E, Abou-Taleb A, Salah H, Baghdadi H, Maria RA, dkk. Percutaneous excretion of iron and ferritin (through Al-Hijamah) as a novel treatment for iron overload in beta-thalassemia major, hemochromatosis and sideroblastic anemia. Med Hypotheses. 2014;83(2):238-46.

32. Samiasih A. Peluang bekam basah mencegah penyakit jantung koroner akseptor KB DMPA (indikator lipid dan respon imun). Prosiding Konferensi Nasional PPNI Jawa Tengah; 2013. h. 187-92.

33. Westlund KN. Pain pathways: peripheral, spinal, ascending, and descending pathways. Dalam: Benzon HT, Rathmell JP, Wu CL, Ruth DC, Argoff CE, Hurley RW, editor. Practical management of pain. Edisi ke-5. Philadelphia: Elsevier Mosby; 2014. h. 87-8.

34. Kapur BM, Lala PK, Shaw JL V. Pharmacogenetics of chronic pain management. Clin Biochem. 2014;47(13-14):1169-87.

35. Yalcin I, Barthas F, Barrot M. Emotional consequences of neuropathic pain: insight from preclinical studies. Neurosci Biobehav Rev. 2014;47:154-69.

36. Lauche R, Spitzer J, Schwahn B, Ostermann T. Efficacy of cupping therapy in patients with the fibromyalgia syndrome-a randomised placebo controlled trial. Nat Publ Gr. 2016;6:37316.

37. Mehta P, Dhapte V. Cupping therapy: a prudent remedy for a plethora of medical ailments. J Tradit Complement Med. 2015;5(3):127-34.

38. Kim JI, Lee MS, Lee DH, Boddy K, Ernst E. Cupping for treating pain: a systematic review. Evid Based Complement Alternat Med. 2011;2011:467014. 